\title{
Perpètua de Cartago i Camar de Tunis. Sobre algunes fonts del Curial accessibles a Itàlia
}

\author{
Perpetua of Carthage and Camar of Tunisia. \\ About some sources of Curial accessible in Italy
}

\author{
ABEL SOLER \\ abel_soler@yahoo.es \\ Universitat de València
}

\begin{abstract}
Resum: Els estudiosos del Curial han relacionat fàcilment l'enamorament de l'africana Camar amb els amors -també africans- d'Enees i Dido. Tanmateix, els ha passat desapercebuda la figura de la màrtir romana Perpètua de Cartago, jove estudiosa de l'Eneida, que fou lligada a un pal i exposada als lleons, entre altres aspectes biogràfics relacionables amb el personatge curialesc de Camar. La revisió de les Actes del martiri (versions A i B, divulgades ensems) i de la novel lada Passio Perpetuae (segle III) permet detectar coincidències argumentals i connexions intertextuals amb la novel la cavalleresca del segle XV. El fet que aquestes fonts foren fàcilment accessibles a Itàlia (Milà, Nàpols), però no a la Península Ibèrica, reforça la idea -generalment acceptada per la crítica- d'un Curial e Güelfa escrit en relació amb la cort napolitana d'Alfons el Magnànim. El tractament paròdic que l'anònim fa de les fonts devocionals, d'altra banda, resulta també especialment interessant per a caracteritzar-lo intel lectualment i per a interpretar l'obra com cal.
\end{abstract}

Paraules clau: santa Perpètua de Cartago, Camar, Curial e Güelfa, novel la cavalleresca, Passio Perpetuae et Felicitatis.

Abstract: The scholars of the Curial have easily related the love of the African Camar with the love stories -also African - of Eneas and Dido. However, they have not paid attention to the figure of the Roman martyr Perpetua of Carthage, a young scholar of the Eneida who was tied to a post and exposed to the lions, among other biographical aspects that could be linked to the character of Camar in the Curial. The revision of the Minutes of the martyrdom (versions A and B, released together) and the fictionalized Passio Perpetuae (3rd century) allow us to notice coincidences in the plot and intertextual connections with the chivalric novel of the 15th century. The fact that these sources were easily accessible in Italy (Milano, Naples) and unknown in the Iberian Peninsula reinforces the idea -generally accepted by the criticism- of a Curial e Güelfa written in relation with the court in Naples of Alfonso the Magnanimous. The parodic treatment that the anonymous writer makes of the devotional sources also seems to be especially interesting to describe him intellectually and to interpret the work properly.

Keywords: St Perpetua of Carthage, Camar, Curial and Guelfa, chivalric romance, Passio Perpetuae et Felicitatis. 
En aquest article pretenem cridar l'atenció sobre l'aprofitament que féu l'anònim autor del Curial -obra molt relacionada amb la Itàlia d'Alfons el Magnànim- dels textos existents sobre la passió de la màrtir Perpètua de Cartago (181-203) per a «construir» el personatge de Camar i el seu entorn familiar, d'una manera «hibridada» amb la Dido de l'Eneida. Normalment, la crítica literària ha vist en els amors virgilians d'Enees i Dido un evident motiu d'inspiració per a fer que una jove i culta donzella de Tunis, Camar, s'enamore passionalment de l'esclavitzat cavaller Curial/ Johan en un escenari geogràfic molt pròxim a la localització dels palaus de la reina cartaginesa. Tanmateix, ha passat totalment desapercebuda als estudiosos l'ombra que la cèlebre màrtir de Cartago - protagonista d'una de les obres literàries més interessants de la baixa romanitat- projecta sobre el personatge de ficció de la novel la italocatalana que és el Curial.

Víbia Perpètua, que així s'anomena en el segle santa Perpètua, ${ }^{1}$ és una dona de noble llinatge romà: «de nobili genere», «nobilique quidem saeculo patre generata», segons els textos o versions A i B, respectivament, de l'acta de martiri. La seua família, com la del Faraig Avdilbar del Curial, resideix als afores de la gran ciutat, Cartago (vora el Tunis del segle XV). El pare ha educat la jove en els estudis liberals, que inclouen -com tot seguit veurem- la lectura de textos clàssics, entre els quals ocupa un lloc privilegiat l'Eneida. La seua vida està recollida en dues fonts diferents: les versions A i B de les Actes del seu martiri, i el relat novel lat -en part autobiogràfic- de la Passio Perpetuae (segle III).

Casada honorablement («matronaliter nupta», Passio Perpetuae, II,1; Heffernan, 2012: 105), Perpètua ha tingut un fill i està embarassada, als seus 22 anys d'edat, d'una filla que parirà a la presó, en vespres de morir per la seua fe. El diaca Satur, amb el seu catecisme, fa que s'interesse per les sagrades escriptures i decidisca fer-se cristiana, amb la qual cosa la catecúmena -deixebla de Satur, com Camar ho serà de Joan- s'integra en un petit grup de cristians clandestins, del qual formen part Revocat, Felicitat, Satur i Secúndol. El marit de la jove Víbia és absent, se suposa que per negocis propis, i, a més de desconéixer la conversió de la dona, no intervé per a res en el drama familiar que precedeix el martiri.

Quan el pare de la jove -i responsable màxim del seu honor, fins i tot casada, segons la tradició romanas'assabenta de la conversió de Perpètua a la mística secta judaica, s'enfureix amb ella i tracta de convéncer-la iradament perquè es retracte, perquè no deshonre tan noble família. No pot aconseguir, emperò, que apostate: "Christiana sum!», exclama de manera insistent ella, i ho repeteix amb fermesa. La preocupació del pare pel destí de la filla és lògica i justificable: l'emperador Septimi Sever està promovent des de fa mesos una furibunda persecució contra els cristians, que són lliurats als lleons als amfiteatres. El conflicte paternofilial és un element central de la tragèdia i apareix reflectit en els capítols III, V, VI i IX de la Passio Perpetuae.

Aprofitant una absència del seu progenitor, que solia desplaçar-se per negocis a la propera ciutat de Cartago, Perpètua es bateja. El grupuscle de cristians és descobert i són empresonats tots. Estant al calabós, la màrtir imminent participa de diverses visions fabuloses: una escala que puja al cel i

\footnotetext{
1 La seua festa se celebrava a Nàpols el 7 de març, tot coincidint la festa amb la del napolità sant Tomàs d'Aquino, protector de la noble casa dels D’Àvalos-Aquino, tan ben relacionada amb Alfons el Magnànim..
} 
un drac; un hort celestial amb un pastor; un gladiador egipci contra el qual lluiten ella -convertida prodigiosament en home- i altres joves; un germà que se li havia mort; escenes d'àngels, etc. Els somnis o visions, $\mathrm{i}$ les tribulacions i pensaments d'ella i dels seus companys màrtirs, són relatats per Perpètua en primera persona en la Passio, com si es tractada d'un diari. La relació inclou l'interrogatori a què la sotmet el procurador Hilarià i una altra forta discussió mantinguda amb el pare.

Amb l'adveniment del natalici del cèsar Gela, fill de l'emperador, els obstinats reus són conduïts a l'amfiteatre per a ser devorats per les bèsties. Les actes del martiri, que marquen el guió de l'hagiografia popular més divulgada, parlen de «lleons»; mentre que la Passio autobiogràfica, conclosa per un anònim redactor, hi fa intervenir un ós, un lleopard i una vaca enfurida, que ataca a la santa. Els altres màrtirs són nafrats i morts per les feres, o degollats per un botxí. Però quan aquest arriba al pal on està lligada Perpètua, es deté temorós. A més a més, com és nou en l'ofici, provoca dolor a la santa perquè talla tocant os. La màrtir li agafa la mà i la redreça cap al tou del coll per a ajudar-lo a degollar-la de manera eficient. Les conviccions i la determinació de la dona, i l'anhel que tenia de rebre martiri, posen en evidencia els dubtes d'un botxí inexpert i perplex.

El martiri de santa Perpètua i dels seus companys (d'on els hagiògrafs fan destacar també el mèrit de la jove esclava Felicitat) esdevingué popular en l'edat mitjana per trobar-se inclòs en divulgadíssimes lectures devocionals: els florilegis de sants o flores sanctorum. La Legenda aurea o Historia Lombardica del dominicà i arquebisbe de Gènova Jacopo da Varazze o della Voragine (12301298) és la compilació d'aquest tipus més coneguda. No hi ha dubte que l'autor del Curial i els seus lectors la coneixien i l'havien oïda recitar, com molts dels seus contemporanis. Fins i tot, no resulta difícil trobar en el Curial algunes connexions intertextuals amb altres relats inclosos en la compilació de Della Voragine. Per exemple, la frase on santa Cecília (en la Vida d'aquesta santa atribuïda a Simó Metafrast) al ludeix a «dare lutum et accipere aurum» troba reflex en la paròdia homilètica del sermó de Sanglier, inclosa en el llibre III de Curial e Güelfa. Comparem textos, doncs:

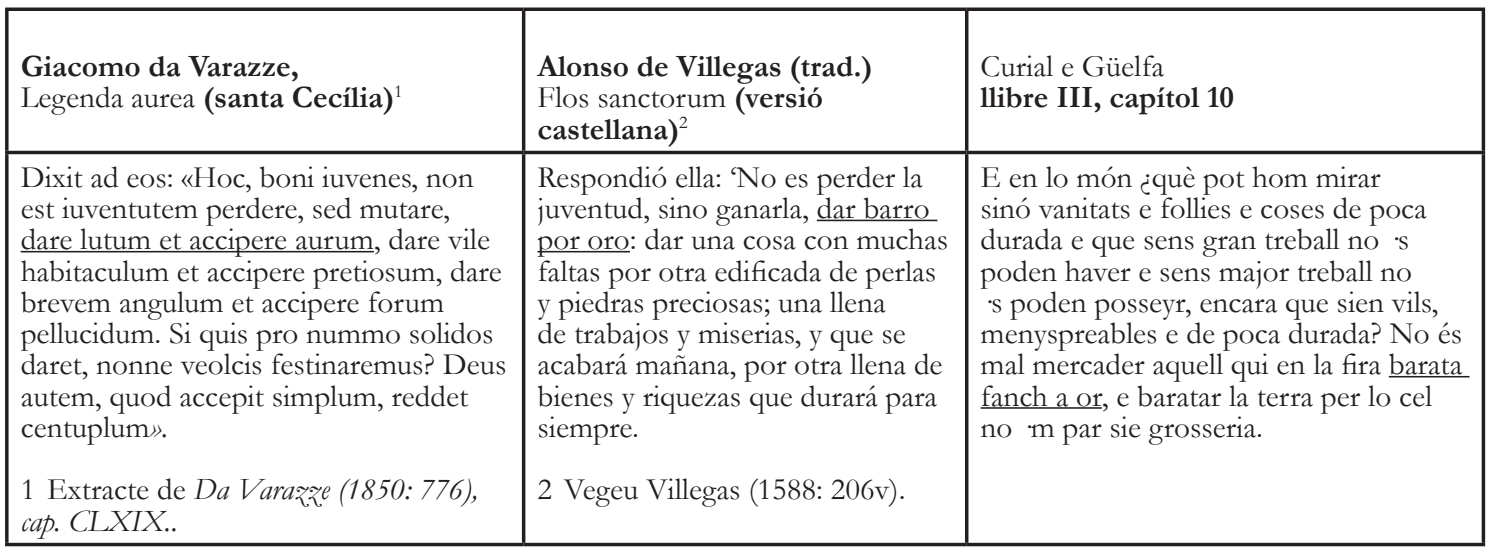


Traduïda a les més diverses llengües, la Llegenda daurada dramatitzava alguns dels aspectes més morbosos dels martiris, sintetitzant a partir de les acta martyrum. Quant a la hagiografia de Perpètua i Felicitat, de la qual venim tractant, Della Voragine aporta el detall següent: «Extracti igitur de carcere, ligatis post ergum manibus et nudatis natibus, per plateas ducuntur et, dimissis bestiis, Satyrus et Perpetua, a leonibus devorantur» (Da Varazze 1850: 797-798, cap. CLXXIII). En la versió castellana de Ribadeneyra diu: «Puestos que fueron en el anfiteatro, atadas las manos, soltaron leones y leopardos para que los despedazasen. Y assí, los leones despedazaron a santa Perpetua y a Sátiro, y los leopardos a Felicitas y Revocato... ». ${ }^{2}$ D’aquests materials hagiogràfics, de divulgació europea, obtingué referents iconogràfics l'anònim pintor del frontal gòtic de Santa Perpètua de Mogoda (Catalunya, ca. 1325) ${ }^{3}$ a l'hora de representar Perpètua lliurada a la fúria dels lleons, en una espècie de corral (l'amfiteatre), per un monarca tirànic, que deu interpretar-se com el procurador Hilarià de Cartago (Melero-Moneo 2005: 75; Pladevall 2005: 70).

La font -anterior, primària- que serví per documentar el breu relat de Da Varazze sobre Perpètua fou alguna de les versions llatines (text A o text B) de l'acta notarial del martiri. Ambdues es copiaven conjuntament en manuscrits medievals, per no saber-se quina podia ser la més autèntica o fidedigna. Se les titulava Acta (brevia) Sanctarum Perpetua et Felicitatis (fi del segle IV). Se sap, emperò, que eren el resum d'una més extensa i detallada Passio Sanctarum Perpetua et Felicitatis (primeries del segle III), atribuïda a l'apologeta Tertulià (en realitat, no és seua, però sí d’algú pròxim a ell), en la qual s'incloïen alguns capítols autobiogràfics: el «diari» dels darrers dies de la santa, adés referit. Agustí d'Hipona comenta que la Passio es llegia en els segles IV-V a les esglésies de l'Àfrica romana (l'actual Tunísia islàmica) per a fomentar la fe dels creients. Tanmateix, aquesta Passió novel lada gaudí d'una molt restringida difusió en l'edat mitjana. Sols estava a l'abast d'alguns lletraferits. Se n'ha conservat tan solament un manuscrit grec trobat a Jerusalem i nou manuscrits llatins dels segles X-XII. Els dos més fidedignes es trobaven a Nàpols (Casinensis 204 MM, ss. X-XI) i a Milà (Ambrosianus C. 210 Inf, ss. XI-XII); els altres set, en diferents biblioteques d'Alemanya, França i Anglaterra (Pseudo-Tertulià 1936: I, 17).

El còdex Casinensis és el text més complet, emprat encara a hores d'ara per a edicions crítiques i filològiques (Heffernan 2012: XII). Passà a integrar-se en la biblioteca del famós monestir benedictí de Montecassino, potser amb altres manuscrits -com el mateix cançoner de Montecassino, que conté poemes de la cort napolitana del Magnànim- procedents de la cort o la ciutat de Nàpols. En dita biblioteca benedictina fou «descobert» per Lucas Holstenius (1596-1661) que en preparà una edició en alemany (pòstuma, 1663). A partir d'aquesta exitosa publicació se n'efectuaren noves impressions i la Passio es popularitzà a Centreeuropa. Les acta brevia o versions abreujades del martiri foren publicades per Henri de Valois (1603-1676) el 1664 amb el títol conjunt Passio SS. Perpetuae

\footnotetext{
2 Versió castellana de Ribadeneyra (1761: I, 440).

3 Aquesta peça d'art, procedent del municipi de Santa Perpètua de Mogoda (el Vallès), es troba exposada en l'actualitat al Museu Diocesà de Barcelona.
} 
et Felicitatis, el qual es presta a confusió amb el de la Passio extensa o pròpiament dita. La primera edició crítica conjunta dels tres textos (la Passió, més l'acta A i l'acta B) la realitzà Cornelius van Beek el 1936 (Bremmer, J. N. / Formisano, M. 2012: 2-3).

L'anònim redactor de la Passio literària o pròpiament dita introdueix la història (capítols I-II), que ve seguida de la part autobiogràfica atribuïda a la santa (III-IX) i d'una visió contada personalment pel seu company i amic Satur (XI-XIII). El mateix redactor que havia encapçalat el text, relata el martiri i introdueix la cloenda (XIV-XXI). Així que es pot parlar d'una triple autoria per al text de la Passio, conclòs pels anys 203-209 (Heffernan 2012: 16), immediatament posteriors al martiri. L'acta martirològica és d'unes dècades després. La part autobiogràfica de la Passio comença in medias res, amb una forta discussió que mantenen el pare i la filla, quan aquesta ja ha decidit fer-se cristiana.

Des del punt de vista literari, la Passió de santa Perpètua es considera com una de les obres literàries més interessant del cristianisme primitiu o tardoromà (Salvatorelli 1936: 10-12). Entre altres coses, perquè conté, com a cosa excepcional, l'autobiografia d'una jove culta del segle III. En el moment en què ella s'educa, s'estudia a les escoles africanes, amb molt de deteniment, l'Eneida de Virgili. I encara en temps de sant Agustí, com ell mateix ho recorda en les Confessiones. Això fa que la formació intel lectual de la màrtir estiga molt mediatitzada o influïda per aquesta lectura, com ho constata Walter Ameling (Ameling 2012). Troba així mateix Peter Dronke que l'Eneida fou «the most important literary stimulus to the images in her dreams [els somnis de Perpètua] may well be Virgil than the Bible». Els recursos literaris i les imatges que genera la santa en la part autobiogràfica de la Passio estan inspirats «in part by Perpetua's reading of the Aeneid» (Dronke 1984: 7-8). Tant és així que alguns crítics, com és el cas de William Farina, es refereixen fins i tot a la Passio com «the Christian Aeneid», l'Eneida cristiana (Farina 2009). Se sobreentenen en aquesta comparança dues premisses: 1) que la lectura i estudi del suïcidi per amor de Dido relatada per Virgili pogué haver influït en la determinant actitud de la màrtir a l'hora de morir per la fe, i 2) que la mort de Perpètua, exemplar per al fidel cristià, superava en mèrits la trista mort de Dido, rebutjada en la patrística per ser «històricament falsa».

Amb tot el que venim dient, és evident que els paral lelismes entre la situació l'africana Camar del Curial i la Perpètua del segle III són més que evidents: ambdues viuen als afores de Cartago/Tunis; són de noble família, ben instruïdes; es troben enfrontades amb els respectius pares, que solen desplaçar-se sovint a ciutat per a descans d'elles; són dones que mostren fortes conviccions, fins al punt de donar-se mort si cal; compten amb el suport d'un catequista (Satur) o d'un «maestre» (Curial), que les anima o estimula a aprofundir en aquestes conviccions, bé siguen religioses (Perpètua) o filosoficomorals (Camar); manegen virilment el ganivet o «coltell» per a autolesionarse, si convé; ambdues són portades a un recinte (amfiteatre, corral) i exposades als lleons en un pal, encara que en molt diferents circumstàncies (l'una, encara viva; l'altra, ja morta), i el seus cossos nuus són coberts a la vista dels espectadors per raons de pudicícia. Per si encara foren poques les coincidències -tramades, evidentment, per l'autor del Curial-, ambdues joves són estudioses o lectores del poema èpic de Virgili, una obra que influirà en el seu ànim i determinació. El suïcidi 
literari de Dido sembla estimular, en ambdós casos -amb una lectura i estudi atent de l'Eneida per Víbia i per Camar- la tràgica i dràstica decisió d'autoimmolar-se. De fet -i aquest és un element clau per a la interpretació filosoficomoral dels episodis africans del Curial-, tant Perpètua (fides) com Camar (ratio) es mostren disposades a superar en positiu l'exemple moralment inacceptable de Dido (passio). Certament, l'hagiografia de Perpètua reescriu i «rectifica» el cas poètic de Dido des d'una perspectiva moral cristiana. En canvi, l'autor del Curial fa paròdia -subtil, només perceptible per part d'alguns lectors «confidents»- del «Christiana sum!» de la santa africana, quan planteja el suïcidi de Camar en clau provocativa: laica i estoica, seguint l'exemple de Cató. L'escriptor del segle XV, d'un segle XV molt italià, reivindica humanísticament -i humorísticament també- la superioritat intel lectual de la filosofia antiga (la de Plató, Aristòtil, Sèneca, Ciceró, Cató d'Útica...) sobre una doctrina moral cristiana -de caràcter teocèntric, místic i limitador- que condemnaria sense pal liatius el gest de Camar. En definitiva: el seu plantejament és «modern» i rompedor.

Tot forma part, en qualsevol cas, d'un planejament narratiu exempt d'improvisacions, minuciosament treballat, com tot el llibre. Ja no cal veure com una ocurrència o idea d'inspiració sobrevinguda com suggereix una part de la crítica- el fet que l'anònim escriga: «E, com Càmar dels catius se partia, legia l'Eneydos de Virgili (...) e molts altres libres (...); e era tan entesa, segons la sua tendra edat, que açò era una gran maravella. E Johan, que sabia molt bé tot lo Virgili e los altres libres, li declarava moltes coses que ella no sabia ne entenia» ( $C e G$ III.43). Com sol ser habitual en el redactor del Curial, tot està previst per a dur-nos, conflicte familiar i moral entremig, cap a un final tràgic on Camar evoca la folla decisió de Dido, parodia el martiri de Perpètua i consuma un suïcidi estoic. L'eclecticisme i la hibridació de fonts, tant en aquest episodi africà del Curial com en altres molts de la novel la, tindria uns efectes altament estimulants, des d'una perspectiva intel lectual, per a alguns dels lectors de l'obra, informats sobre debats humanístics.

El vincle entre lectura d'un comportament moral en la ficció i l'infux de les vides «fingides» en la vida real (és a dir: Camar coneix la mort de Dido i, en acabant, la imita) és el fet més evident i remarcat pels estudiosos, i és també, potser, la cosa menys original. Com observa Isabel Grifoll, l'escriptor recordaria segurament el cant $\mathrm{V}$ de l'Inferno de Dante, on la jove parella de Paolo i Francesca resten extasiats «davant l'escena de Galehot al Lancelot en prose. El fet que l'anònim insisteixi en l'enamorament de Camar per la bellesa de Curial, com la de Rímini per Francesco», d'altra banda, constitueix «un ingredient de fenomenologia amorosa absolutament reiterat en l'ars amandi, però insòlit aplicat a un subjecte femení. El bes de Camar a Curial, celebrat per la crítica, que recorda el de Francesca a Paolo, és tan dolç com amarg en la desgràcia». (Grifoll 2013: 55). El subjecte femení com a actor i protagonista de situacions: això sí que és original, doncs, i es repeteix amb altres personatges femenins del llibre. El caràcter «insòlit» que Grifoll atribueix a la iniciativa amorosa empresa per Camar, ja no resulta tan insòlit quan s'observa que la iniciativa de l'amor en Curial e Güllfa-sense comptar-hi ara altres iniciatives no estrictament amoroses- és una cosa de tres dones. Ni la Güelfa, ni Làquesis, ni Camar es resignen a ser objectes passius del sentiment amorós (Gros 2015: 75). Curial, en realitat, és un cavaller que no emprén batalles d'amor, sinó que es veu atrapat en les faldes (Güelfa), els llaços (Làquesis) o els braços (Camar) de tres dones decidides a fer-lo seu. 
Tornant al cas específic que ens ocupa, el del vincle identitari Camar-Perpètua, un dels elements argumentals més interessants que connecten les Acta i la Passio amb el Curial és el de la conflictiva relació entre Camar i «lo mesquí de pare» (Ce $G$ III.48) que li havia tocat suportar, que l'escriptor descriu com un viciós (CeG III.42):

\footnotetext{
Son pare ere tan gelós, no solament de la filla, ans encara de la muller, que bellíssima dona era, que nulls temps a la ciutat les lexava anar, ans les tenia en aquella casa, no solament apartades, ans amagades; e ell anava-sse'n a Túniç, on tenia altra casa e altres mullers, e ab aquelles, e altres encara que cercava, axí com aquell qui era molt luxuriós e viciós d'aquell pecat, e en ell molt enfangat e ensutzat, e axí vivia.
}

El tòpic rebuig de la poligàmia islàmica i de la luxúria dels musulmans és un motiu recurrent en aquests capítols africans de la novel la cavalleresca. El català Bernat Metge (Lo somni, I, vi, 51) reflecteix aquesta apreciació com a proverbial entre els cristians. Observa que l'Alcorà promet un Paradís amb «moltes punçelles, ab les quals los moros de Déu jauran» i dedueix que no sols els seus costums, sinó també «la sua doctrina és favorabla e disposta a luxúria e altres delits carnals» (Metge 2006: 158).

En emulació del pare de Perpètua, el Faraig Avdilbar del Curialsol absentar-se de l'alqueria periurbana per a desplaçar-se algunes temporades a la ciutat, on disposa d'una segona residència i on es dedica als negocis (i a mantenir relacions «vicioses» amb algunes de les seues diverses mullers). Quan el pare de Perpètua torna de la capital al camp i es troba amb la resistència d'aquesta a abandonar la seua fe, es desencadena la violenta discussió entre pare i filla. La pugna familiar o paternofilial, en el cas de la novel la del segle XV, es precipita també quan el pare torna de la ciutat per a demanar a la seua filla que es case amb el rei tirà de Tunis. L'exigència del monarca, que obliga la jove a renunciar al seu amor per Joan/Curial, és la que precipita la tragèdia (Ce $G$ III.44 i ss.).

Així, com una nova Perpètua, Camar es queixa a Curial de l'actitud de son pare ( $C e G$ III.51):

\footnotetext{
Sàpies que yo, en mon cor havent a tu atorgada la mi amor, fuy per mon pare requirida que casàs ab lo rey, lo qual volia lo meu matrimoni. E per ço que mon pare a força me volia menar al rey, no sabent yo altra manera per la qual me'n pogués escusar, aprés de moltes rahons passades entre mon pare e mi, ferím ab un coltell en los pits, e fi u-me gran nafra, jatsia en los meus ulls, en sguart de ço que yo per tu faria, sia petita molt.
}

Imitant paròdicament el conflicte de Perpètua, Camar es queixa amargament de la tirania del seu pare, i es mostra disposada a passar-se el ganivet per la gola i llevar-se la vida, si no veu cap altra eixida, atrapada com està entre dos tirans. La seua personalitat i la determinació que manifesta semblen tan fortes com les de la santa de la Passio. En les actes del martiri de Perpètua, en efecte, assistim a discussions familiars o disputes com les que protagonitzen Camar i els seus pares (Acta 
A, II, 1-3). Però sobretot, es tracta d'un dramàtic estira i arronsa entre un pare i una filla rebel (Terranova 2011: 179-185):

[1] Audiens vero pater Perpetuae eam esse comprehensam cucurrit ad carcerem, et videns eam dixit: «Quid hoc fecisti, filia? Dehonestasti enim generationem tuam. Numquam enim de genere nostro aliquis missus est in carcerem». [2] Perpetua vero dixti ad eum: «Pater». At ille respondit: «Quid est filia?» Perpetua dixit: «Ecce verbi gratia vides vas iacens aut facile aut cuiuslibet generis?» Et ille respondit: «Video. Quid ad haec?» Perpetua dixit: «Numquid ailud nomen potest habere quam quod est?» At ille respondit: «Non». Perpetua dixit: «Sic nec ego ailud nomen accipere possum quam quod sum: Christiana». [3] Tunc pater eius, audito hoc verbo inruit super eam, volens oculos eius eruere; et exclamans, confusus, egressus est foras (Pseudo-Tertulià 1936: I, 60).

I encara més avant (Acta A, VI, 3): «Perpetua (...) dixit ad patrem suum: “Pater, noli vereri: Perpetuam enim filiam tuam, si non obstineris, perpetuam filiam possidebis"” (Pseudo-Tertulià 1936: I, 68). En la Passio de la santa s'insisteix més extensament (III,1-3):

[1] «Cum adhuc» inquit cum prosecutoribus essemus et me pater verbis evertere cupiret et deicere pro sua affectione perserveraret: «Pater», inquam, «vides berbi gratia vas hoc iacens, urceolum sive aliud?» Et dixit: «Video». [2] Et ego dixi ei: «Numquid alio nomine vocari potest quam quod est». Et ait: «Non». «Sic et ego aliud me dicere non possum nisi quod sum, Christiana». [3] Tunc pater motus hoc verbo mittit se in me ut oculos michi erueret, sed vexavit tantum et profectus est vinctus cum argumentis diaboli. [4] Tunc paucis diebus quod caruissem patre, Domino gratias egi et refrigeravi absentia illius (Bremer / Formisano 2012: 25).

Després assistim en el mateix relat al baptisme de la jove, l'empresonament, les visions i una visita del pare al calabós (IV, 1-2):

[1] Post paucos dies rumor cucurrit ut audiremur. Supervenit autem et de civitate pater meus, consumptus taedio, et ascendit ad me, ut me deiceret, dicens: [2] «Miserere, filia, canis meis; misereri patri, si dignus sum a te pater vocari; si his te manibus ad hunc florem aetatis provexi, si te praeposui omnibus fratribus tuis; ne me dederis in dedecus hominum (...)». [5] Haec dicebat quasi pater pro sua pietate basians mihi manus, et se ad pedes meos iactans et lacrimas me iam non filiam nominabat sed dominam. [6] Et ego dolebam casum patris mei quod solus de passione mea gravisurus non esset de toto genere meo, et confortavi eum (...) (Bremer / Formisano 2012: 26).

És evident, doncs, que l'oposició entre un pare tirànic i una filla amb fermes determinacions -una heroïna en potència- estimulà la creativitat de l'anònim a l'hora de «dissenyar» el personatge de Camar i el seu entorn. Com també li serví d'estímul creatiu la reproducció d'aquesta oposició paternofilial entre la resoluta donzella Ghismonda de la novella IV.1 del Decameron, i el seu cruel i venjatiu progenitor (Gros 2015: 244-247). Tanmateix, Ghismonda ja ha servit de referent en el 
debat mantingut per Làquesis amb sa mare, la duquessa de Baviera. Ara és el torn d'evocar la màrtir africana.

La neòfita Perpètua és interrogada al Fòrum de Cartago pel procurador Hilarià, que comprova la contumàcia de la rea (VI, 4): «Hilarianus: "Christiana es?” inquit. Et ego respondi: "Christiana sum!”» (Bremer / Formisano 2012: 26). Després d'altres noves visions, tingudes a presó, Perpètua rep una última visita d'un pare desesperat (IX,2-3):

[2] Ut autem proximavit dies muneris, intrat ad me pater meus consumptus taedio, et coepit barbam suam evellere et in terram mittere, et prosternere se in faciem, et inproperare annis suis, et dicere tanta verba quae moverent universam creaturam [3] Ego dolebam pro infelici senecta eius (Bremer / Formisano 2012: 27-28).

Es compten a continuació nous somnis tinguts a la cel la, així com el part de la màrtir a la mateixa presó, abans de finalitzar el relat en primera persona. És llavors quan entra la veu del narrador en tercera persona, per a contar-nos el martiri.

A partir dels diversos testimonis narratius del martiri, s'extrauen interessants lligams intertextuals, que ajuden a entendre el biaix en certa manera paròdic del Curial:

\begin{tabular}{|c|c|}
\hline $\begin{array}{l}\text { 1) Anònim, } \\
\text { Curial e Güelfa, III.66 }\end{array}$ & $\begin{array}{l}\text { Acta brevia Sanctarum Perpetuae e Felicitatis (A, V, } 5 \text { i } \\
\text { 9) }\end{array}$ \\
\hline \multirow[t]{3}{*}{$\begin{array}{l}\text { Per què, Johan, aparella a mi los teus braços e d'aquells } \\
\text { fes lit en lo qual muyra. Reeb-me, Senyor, que a tu vaig: } \\
\text { christiana són e he nom Johana! Recomana al Déu teu } \\
\text { la mia ànima, e lo cors en la tua terra hage sepultura. }\end{array}$} & $\begin{array}{l}\text { "Christiana sum, et ut mererar esse perpetua, in Christi } \\
\text { nominis confessione permaneo» (...) Proconsul ad Perpetuam } \\
\text { dixit: "Quid dicis, Perpetua? Sacrificas?» Perpetua respondit: } \\
\text { "Christiana sum, et nominis mei sequor auctoritatem, ut sim } \\
\text { perpetua". } \\
\text { 3 Citem a partir d'Anònim (1936: 66). }\end{array}$ \\
\hline & Acta brevia Sanctarum Perpetuae e Felicitatis $(\mathbf{B}, \mathbf{V}, \mathbf{5})^{4}$ \\
\hline & $\begin{array}{l}\text { Sancta Pepetua respondit: "Christiana sum, et ut merear esse } \\
\text { perpetua, in Christi nominis confessione permaneo } " . ~ \\
4 \text { Ibídem, p. } 67 .\end{array}$ \\
\hline 2) Anònim, Curial e Güelfa, III.67-68 & $\begin{array}{l}\text { Perpètua, Satur i al., } \\
\text { Passio sanctae Perpetuae et Felicitatis, I, } \mathbf{1}^{5}\end{array}$ \\
\hline $\begin{array}{l}\text { Càmar (...) legia l'Eneydos (...) e molts altres libres (...), } \\
\text { e era tan entesa, segons la sua tendra edat, que açò era } \\
\text { una gran maravella. }\end{array}$ & $\begin{array}{l}\text { [Víbia Perpetua], femina liberaliter instituta. } \\
5 \text { Bremer / Formisano (2012: 105).. }\end{array}$ \\
\hline
\end{tabular}


3) Anònim, Curial e Güelfa, III.59-60

...e ab aquells envessos dels labis lo besà (...). E Johan, près comiat (...). E Càmar romàs en lo lit, lavant $a b$ la lengua los seus labis, per pendre lo çucre d'aquella poca de saliva que dels labis de Johan en los seus ere romasa (...). Pens cascú qui enamorat és estat, com són plasents aquells pensaments e com és dolça aquella solitut.

\section{Perpètua, Satur i al.,}

Passio sanctae Perpetuae et Felicitatis, IV, 9-10

[9] Et clamavit me et de caseo quod mulgebat dedit mihi quasi buccellam; et ego accepi iunctis manibus et manducavi; et universi circumstantes dixerunt: «Amen». [10] Et ad sonum vocis experrecta sum, commanducans adhuc dulce nescio quid. Et (...) intelleximus passionem esse futuram, et coepimus nullam iam spem in saeculo habere.

6 Ibídem, p. 26.
4) Anònim, Curial e Güelfa, III.67-68

Lo rey rabiava de mal talent, e manà que

en aquell punt lo catiu e Càmar fossen donats als leons

(...). [Curial] despullat, en camisa fonch mès en lo corral. Ja la desaventurada Càmar, tota nua, que no semblava persona, era en lo corral, ben ligada a un pal.
Acta brevia Sanctarum Perpetuae e Felicitatis (A, IX,34) ${ }^{7}$

[El diaca Sàtur i santa Perpètua] positi sunt in medio amphitheatri nudi, ligatis post tergum manibus; et dimissis bestiis diuersis, $\underline{\text { Satvrus et Perpetua a leonibus sunt deuorati. }}$

7 Anònim (1936: 66).

Acta brevia Sanctarum Perpetuae e Felicitatis (B, IX,3) ${ }^{8}$ ...nudi et post teroum manibus conligati in medio amphitheatri statuuntur (...). Missi leones diuturna fame confecti et ad adcelerandam gloriam martyrum humana industria praeparati. Beatum Saturum et Perpetuam furentes leones invadunt.

8 Ibídem, p. 67.

\section{Perpètua, Satur i al.,}

Passio sanctae Perpetuae et Felicitatis, XX, 2-59

Itaque dispoliata[e] (...), prior Perpetua iactata est, et concidit in lumbos. Et ubi sedit, tunicam a latere discissam ad velamentum femoris reduxit, pudoris potius memor quam doloris.
9 Bremer / Formisano (2012: 31).
Los dos cavallers corren e entren en lo corral. E En Ramon Folch despullà's un manto molt rich e més-lo damunt lo catiu. Curial en un punt lo's hach despullat e 1 més sobre Càmar, e ab aquell cobrí les sues carns nues; e, ficant lo genoll davant ella.

\section{6) Anònim, Curial e Güelfa, proemi al llibre} III.48

...e viu un coltell qui estava sobre un banch, e, corrent, pres aquell, e dix: $-\mathrm{Tu} \mathrm{m}$ defendràs del rey- $\underline{\mathrm{E} \text { ferís }}$ ab lo coltell pels pits. E com se ferís, sens manera dubtant

ésser empatxada, no entrà dret lo coltell, ans biaxà per la mamella esquerra, e no li entrà en lo tou del cors.

\section{Perpètua, Satur i al.,}

Passio sanctae Perpetuae et Felicitatis, XXI, 9-10 $\mathbf{1}^{10}$

[ix] Perpetuam autem, ut aliquid doloris gustaret, inter ossa conpuncta exululavit, et errantem dexteram tirunculi gladiatoris ipsa in ugulum suum transtulit. [x] Fortasse tanta femina aliter non potuisset occidi, quae ab inmundo spiritu timebatur, nis ipsa voluisset.

10 Ibídem, p. 32. 


\begin{tabular}{|c|c|}
\hline $\begin{array}{l}\text { 7) Anònim, Curial e Güelfa, proemi al llibre } \\
\text { III, etc. }\end{array}$ & $\begin{array}{l}\text { Acta brevia Sanctarum Perpetuae et Felicitatis (B, IX, } \\
\mathbf{5}^{11}\end{array}$ \\
\hline $\begin{array}{l}\text { Concloent, donchs: com lo pus estret juyhí, ans estrem } \\
\text { dels estrems, en actes militars, sie la liça, la qual Curial } \\
\text { més que algun altre, no ell cercant-la, mas ella seguint- } \\
\text { lo, hage usada, no digam los seus valerosos actes ésser } \\
\text { indignes de recordació venerable; car, si per ventura } \\
\text { fossen estats escrits per Tito Lívio, per Virgili, Staci } \\
\text { o algun altre gran poeta o orador, fóran estats legits, } \\
\text { recordats e tenguts en gran stima per hòmens de } \\
\text { reverenda letradura (III.0) }\end{array}$ & \multirow[t]{4}{*}{$\begin{array}{l}\text { Horum ergo beatissimorum martyrum victorias (...) recolere } \\
\text { debet Ecclesia, ut tantis exemplis et tanta utriusque sexus } \\
\text { tolerantia inflammata, etsi pro tempore persecutionis } \\
\text { necessitatem non habet, dum recordatione venerabili } \\
\text { martyrum recenset triumphos, eorum patrociniis Domino } \\
\text { commendetur, qui vivit et regnat in saecula saeculorum. } \\
\text { Amen. } \\
11 \text { Anònim (1936: 73). }\end{array}$} \\
\hline $\begin{array}{l}\text { don Pedro, cavaller molt rebust, forts e valent, lo qual } \\
\text { mentre visqué féu de son cors en batalles moltes coses } \\
\text { dignes de recordable veneració (I.46) }\end{array}$ & \\
\hline $\begin{array}{l}\text { lo rey d'Aragó... havia fetes coses de son cors } \\
\text { dignes de recordable veneració (II.37) }\end{array}$ & \\
\hline $\begin{array}{l}\text { rey d'Aragó, los strènuus actes d'armes del qual, axí } \\
\text { com dignes de recordable veneració (II.113) }\end{array}$ & \\
\hline
\end{tabular}

L'autor del Curial, coneixedor i estudiós de l'obra de Virgili, sembla haver escoltat o llegit la vida i martiri de Perpètua dels flos sanctorum, molt divulgada. Però sembla més evident encara que tingué accés a les actes de martiri originals, que solien circular acompanyades de la Passio sanctarum Perpetuae et Felicitatis atribuïda des de l'edat mitjana a Tertulià. Si és així, és evident que l'escriptor s'hauria de moure - per precisió- per la cort de Milà, en cercles pròxims a l'humanisme, o per la de Nàpols, on hauria conegut el futur manuscrit Casinensis 204: aquell que contenia aquella «anti-Eneida» o Eneida cristiana. És pràcticament impossible que algun escriptor de la Península Ibèrica tinguera accés a aquestes fonts, fàcilment localitzables a Itàlia, raó per la qual les connexions argumentals i textuals manejades ajuden a situar -com tantíssims altres detalls- el lloc d'escriptura del Curial a Itàlia, molt probablement al Nàpols alfonsí.

Es podrien fer, a més, algunes altres consideracions, ja no contextuals, sinó interpretatives, sobre l'interés que tingué l'escriptor -molt amic d'hibridacions- a combinar aspectes de Perpètua i de Dido per a caracteritzar el seu personatge femení. Per exemple, és lògic pensar que la proclama de Camar com a cristiana («Christiana són...!»), just abans de cometre un pecat dels més grossos -el suïcidi-, siga una provocació paròdica de l'autor, basada en la insistència de Perpètua a buscar el martiri amb la mateixa proclama: «Christiana sum...!». Es dedueix que, en l'ambient intel lectual on es movia l'anònim, la Passió de Perpètua fou objecte de controvèrsia entre els teòlegs, perquè Tomàs d'Aquino condemnava taxativament qualsevol tipus de suïcidi, fins i tot el produït en la situació més desesperada. I la Passio explica, pràcticament, que la mateixa santa s’hagué de donar mort en el darrer moment amb un ganivet, enmig de l'amfiteatre, atesa la inexperiència del botxí. Amb la qual cosa, estaria en dubte per als més primmirats teòlegs escolàstics si morí virtuosament 
o no com a cristiana. En les actes del martiri, Perpètua encomana directament l'ànima al «nom» de Crist; en el Curial, ho fa al nom del seu estimat Joan. I si es proclama cristiana és perquè Aquell dels cristians és el déu de Joan. En qualsevol cas, la blasfèmia està servida, perquè la primera cosa que fa l'espontània conversa al cristianisme és atemptar terroríficament contra Déu i la seua obra, per tal com se suïcida. A tot això, el que justifica la seua mort, en realitat i atenent a les seues manifestacions prèvies, és el discurs de base filosòfica estoica que ha sostingut contra sa mare, Fàtima, i no la imprevisible i desafortunada conversió. La hibridació cultural i la curiosa combinació de referents literaris (Cató, Perpètua, Dido) diu molt dels gustos eclèctics de l'escriptor.

El ressò de la frase de Perpètua en el suïcidi de Camar és el gest més cridaner que fa l'anònim del Curial perquè els seus lectors -entre els quals és dubtós que es trobara algun religiós o teòlegrelacionen ambdós personatges (la màrtir i la «mora folla», com l'anomena la Güelfa) i riguen amb ell la paròdia. Però no és l'únic element paròdic o sotmés a un camuflatge humorístic subtil i culturalista, com s'ha vist. Particularment interessant és l'evocació d'una visió celestial amb possible lectura sensual, com és la de Perpètua, en una escena eròtica, que denota la voluntat de parodiar els detalls literàriament més «interessants» del vell relat del martiri. Vegem-ho.

En un determinat moment de la Passio, la jove Perpètua somnia que arriba a hun hort celestial, on els habitants -ànimes pures- visten de blanc i formen un cor al voltant del Bon Pastor. Aquest, el Pare Etern, dóna la benvinguda a la futura màrtir i li ofereix eucarísticament un trosset de formatge. Ella l'accepta i el degusta reverencialment, mentre la resta d'assistents diuen «amen». Llavors Víbia es desperta del somni, però continua assaborint a la boca una dolçor de saliva impregnada de la vianda celestial: «commanducans adhuc dulce nescio quid». Es troba amb el seu germà i ambdós interpreten el somni com un senyal que s'acosta l'hora en què seran martiritzats. D'una manera semblant, en el Curial, Camar acaba de besar Joan, del qual es troba enamorada. Quan aquest se'n torna a l'hort -pel que fa al cas, un hort ben terrenal-, la jove sembla no haver despertat encara del somni d'amor. Es queda també amb la dolçor de la saliva del bes, com un regust en la boca: «lo çucre d'aquella poca saliva que (...) en los seus [llavis] ere romasa». A la Itàlia neoplatònica del segle $\mathrm{XV}$, ja no és el Pare Etern, totpoderós, qui redimeix els homes i en perfecciona les ànimes, sinó l'Amor de la Venus «estel lificada», que és «pus poderosa dea que Fortuna» (CeG III.100), que la Fortuna/Divina Providència de Boeci, s'entén.

La imatge compartida per la Passio i el Curial recorda l'Antic Testament (Càntic dels Càntics, 4:11: «Favus distillans labia tua, sponsa; mel et lac sub lingua tua»), tal volta filtrada o influïda en el cas de la novel la per la poesia petrarquesca o la prosa epistolar de les Familiares V, xvii, 11: «sicui saporiferi favus mellis labiis admotus repente subtraheretur, amotaque dulcedine, sola quidem amara dulcedinis recordatio superesset», i XXIV, vi, 8: «et recordatione torqueor summis, ut aiunt, labiis gustate dulcedinis» (Petrarca 2004 [1997]: s. p.). Influx de Petrarca o no pel mig, la cosa certa és que la Camar de llavis endolcits suposa -especialment per als oients d'una cort com la napolitana, més habituats als flores sanctorum que no a l'estudi de Petrarca- una reedició en clau 
paròdica de l'hagiografia de la jove màrtir africana. Camar de Tunísia, a diferència de Perpètua de Cartago, no preveu encara l'hora ni la forma del seu peculiar «martiri», però el lector informat del cas de Perpètua percep perfectament l'amarga dolçor d'un «çucre» que presagia la tragèdia.

El procurador romà Hilarià esdevé en la ficció novel lesca del segle XV un rei de Tunis que prepara un corral, en lloc d'un amfiteatre romà, on lliurar Curial -transposició parcial del diaca Satur, company de Perpètua- i el cadàver de Camar -la nova Perpètua- als ferotges lleons. Amb aquesta excusa, l'escriptor té el caprici ara de ressuscitar l'infant castellà Enric del segle XIII, perquè ell i els seus amics, lectors de cròniques castellanes, recorden que una d'aquestes cròniques el feia protagonista d'una anècdota molt semblant: amb un «corral» $\mathrm{i}$ uns lleons $\mathrm{i}$ un rei de Tunis (Cortadellas 2001: 30-32).

L'escena gloriosa dels màrtirs lligats a pals i lliurats a les feres esdevé en el Curial una grotesca presentació de les rígides despulles mortals de Camar lligades a un pal, com en el relat martirològic. L'autor no intenta en absolut commoure cap auditori devot sobre aquesta situació, com feien els hagiògrafs, sinó ironitzar novament sobre un detall de la Passio que li fa gràcia. I és que la santa cartaginesa, a punt de morir, demana un mantell per a cobrir-se les cuixes, perquè encara tenia en ella més força el pudor que el dolor que li causaven les envestides de la bèstia... Això explica la introducció d'un espontani gest caritatiu de l'ambaixador Ramon-Folc de Cardona, que «despulla's un manto» per a Curial, i l'ús que en fa aquest a continuació: el «més sobre Càmar, e ab aquell cobrí les sues carns nues». També es pot considerar una paròdia grotesca del martiri -d'una santa tunisenca que està molt present, però que l'autor no nomena explícitament per a res-el fet que Camar agafe un «coltell», com havia fet Perpètua abans de morir, i s'autolesione.

El gest de ferir-se amb un ganivet domèstic com a «heroïcitat» femenina per a impedir o entrebancar l'acció indesitjable d'un home, apareix en Valeri Màxim. Es tracta del cas de Pòrcia, la filla de Cató, que s'autolesiona amb un procediment similar al de Camar a fi d'evitar que el marit, Brutus, arrisque la vida en el complot ordit contra Cèsar. Tant una font, l'hagiogràfica, com l'altra, l'exemple clàssic de Valeri, podrien haver concorregut en la ment de l'escriptor a l'hora d'idear la dramàtica ocurrència de Camar.

Tornant ara al cas de Perpètua, val a dir que contrasta també l'explicit o colofó de les Actes de les santes africanes amb la cloenda del proemi III.0 del Curial. L'escriptor aprofita la reivindicació de la «recordatione venerabili» de les victòries dels màrtirs segons Tertulià (ell i els seus coetanis creuen que la Passio és obra del mateix Tertulià) per a justificar paròdicament la «recordació venerable» de les victòries cavalleresques, laiques del tot, del seu heroi de paper, Curial. Les victòries i els triomfs dels màrtirs augmenten la glòria de l'Església, però també inunden les biblioteques europees de l'època d'una literatura devocional i homilètica de gust i de qualitat més que dubtosos. Les gestes del cavaller de ficció, en canvi, commemoren l'esperit de la historiografia profana i «reverenda» dels antics: aquelles lletres que honoraven els grans emperadors i cèsars. ¿Què és el Curial, si no una divertida manera -literatura d'evasió- d'omplir l'absència d'una epopeia dinàstica i cortesa all'antica, que commemorara el triomf napolità del nou Enees/August del segle XV? 
Fa la impressió que l'anònim del Curial lamentava profundament que les nobles famílies de la cort on habitava perderen les hores amb aquella literatura devocional de «recordació venerable» de verges visionàries i martiris exagerats, que ho envaïa tot, però que era de ridícula o baixíssima qualitat en comparança amb els clàssics grecollatins. De fet, una de les seues intencions, en escriure la seua novel la de cavalleria humanística -i en dotar-la d'un aire jocund, profà i combatiu-, sembla la de respondre a la saturant hegemonia d'obres devotes, moralitzants $i$ hagiogràfiques amb una alternativa sobre l'amor i les armes que fóra pròpia del moment i digna del temps viscut. Encara que, al remat, l'haguera de compartir amb un públic reduït i confident, perquè -per la causa que fóra- no li convenia airejar-la o divulgar-la més ellà. Segurament, seria algú desitjós d'assistir a la regeneració i a l'actualització d'un gènere literari caduc, el de les velles cavalleries, a partir de patrons literaris (Boccaccio) i ideològics (l’humanisme) més concordes amb el temps i «desenvolupats» de rèmores fraresques. Cosa que explica que els cavallers, una mica farts de la intromissió del discurs religiós en àmbit aristocràtic, expulsen el franciscà d'Angers de sang reial (sant Lluís de Nàpols?) pel «destorb» que donava i perquè tractava d'impedir que nobles i cavallers gaudiren del lleure cortesà i de l'exhibició esportiva.

Certament, la divertida pugna literària, ideològica, de la qual s'erigeix en paladí l'escriptor -i no sols pel que afecta a la paròdica evocació de santa Perpètua o sant Lluís- no podia fer-se pública sense que aquest incorreguera en riscos excessius per al seu prestigi. Convenia que fóra discretament «recitada». D’ací que el Curial no fóra publicat obertament, sinó divulgat confidencialment, i que no conste en cap inventari antic. 
Abel Soler. Perpètua de Cartago i Camar de Tunis. Sobre algunes fonts del Curial accessibles a Itàlia

\section{Bibliografia}

Ameling, W. (2012) «Femina Liberaliter Instituta. Some Thoughts on a Martyr's Liberal Education», dins Bremmer, J. N. / Formisano, M. (eds.) Perpetua's Passions. Multidisciplinary Approaches to the «Passio Perpetuae et Felicitatis», amb text i trad. anglesa de J. Farrell / C. Williams, Oxford, Oxford University Press, pp. 78-102.

Anònim (1936) Acta SS. Perpetuae et Felicitatis, dins el llibre del Pseudo-Tertulià, Passio Sanctarum Perpetuae et Felicitatis. Textum graecum et latinum ad fidem codicum mss., ed. a cura de C. Van Beek, Nijmegen.

Cortadellas Vallès, A. (2001) Repertori de llegendes historiogräfiques de la Corona d'Aragó, Barcelona, Publicacions de l'Abadia de Montserrat.

Da Varazze, J. [Iacobus a Voragine] (1850) Legenda Aurea, vulgo «Historia Lombardica» dicta, ad optimum librorum fidem, ed. a cura de T. Graesse, Leipzig, Impensis Librariae Arnoldianae.

Bremmer, J. N. / Formisano, M. (2012) «Perpetua’s Passions: A Brief Introduction», dins Iidem (eds.) Perpetua's Passions. Multidisciplinary Approaches to the "Passio Perpetuae et Felicitatis», amb text i trad. anglesa de J. Farrell / C. Williams, Oxford, Oxford University Press, pp. 1-13.

Bremmer, J. N. / Formisano, M. (eds.) (2012) Perpetua's Passions. Multidisciplinary Approaches to the «Passio Perpetuae et Felicitatis», amb text i trad. anglesa de J. Farrell / C. Williams, Oxford, Oxford University Press.

Dronke, P. (1984) Women Writers of the Middle Ages. A Critical Study of Texts from Perpetua (+203) to Marguerite Porete (+1310), Cambridge, Cambridge University Press.

Farina, W. (2009) «The Christian Aeneid», capítol del llibre Perpetua of Carthage. Portrait of a ThirdCentury Martyr, Jefferson (Carolina del Nord) / Londres, McFarlan \& Inc., pp. 20-26.

Grifoll, I. (2013) «Camar versus Dido», dins A. Clúa / F. Sabaté (eds.) Usos i tradició de les literatures clàssiques a les literatures medievals, Lleida, Pagès, pp. 35-59.

Gros Lladós, S. (2015) «Aquella dolçor amarga». La tradició amatòria clàssica en el «Curial e Güelfa», València, Universitat de València.

Heffernan, T. J. (ed.) (2012) The Passion of Perpetua and Felicity, Oxford, Oxford University Press.

Melero-Moneo, M. (2005) «Frontal de Santa Perpetua de Mogoda», capítol del llibre La pintura sobre tabla del gótico lineal Frontales, laterales de altar y retablos en el reino de Mallorca y los condados catalanes, Lleida, Universitats de Barcelona, Autònoma de Barcelona i Lleida / Museu Nacional d'Art de Catalunya, pp. 72-79.

Metge, B. (2006) Lo somni, ed. a cura de S. M. Cingolani, Barcelona, Barcino.

Petrarca, F. (2004 [1997]), Epystole Familiares, dins Petrarca, F., Opera omnia, ed. a cura de P. Sropelli, Roma, Lexis Progetti1997; reed. electrònica, Biblioteca Italiana, Roma, 2004 <www.

SCRIPTA, Revista internacional de literatura i cultura medieval i moderna, núm. 8 / desembre 2016 / pp. 90-105 ISSN: 2340-4841 · doi:10.7203/SCRIPTA.8.9283 
Abel Soler. Perpètua de Cartago i Camar de Tunis. Sobre algunes fonts del Curial accessibles a Itàlia

bibliotecaitaliana.it> consultada en gener del 2016.

Pladevall, A. (2005) L'art gòtic a Catalunya, I. De l'inici a l'italianisme, Barcelona, Enciclopèdia Catalana.

Pseudo-Tertulià (1936) Passio Sanctarum Perpetuae et Felicitatis. Textum graecum et latinum ad fidem codicum mss., ed. a cura de C. Van Beek, Nijmegen.

Ribadeneyra, P. de (1761) Flos sanctorum, Vidas de los santos, Madrid, Joaquín Ibarra.

Salvatorelli, L. (1936) Storia della letteratura latina cristiana dalle origini alla metà del VI seccolo, Milà, Francesco Vallardi.

Terranova, C. (2011) «Christiana sum. Nuclei tematici nelle redazioni della "Passio Sanctae Perpetuae et Felicitatis"», Bizantinistica. Rivista di studi bizantini e slavi, serie 2, any 13, pp. 171-187.

Villegas, A. de (ed.) (1588) Flos sanctorum nuevo, Venècia, Felice Valgrisio i Angelo Tavan. 